Endocrinol. Japon. 1962, $9(2), 90 \sim 92$

\title{
ION SHIFT IN EXPERIMENTAL HYPERTENSION
}

\author{
LUBOR VACEK
}

\section{Laboratory of the Pathophysiology of Circulation, Second Clinic of Internal Medicine, Medical Faculty, Purkyně University, Brno, Czechoslovakia}

In aorta strips from rabbits with blood pressure elevated by various procedures the author succeeded in demonstrating that the vessel reactivity exhibits marked changes in animals with experimental hypertension (Vacek, 1959 and 1960; Vacek and Texl, 1960). In this paper the author trys to answer the question as to what extent these functional changes reflect the shift in the mineral ions.

\section{METHODS}

Rabbits weighing from 2000 to $2500 \mathrm{~g}$ were divided into the following groups : Group $\mathrm{N}-$ control animals. Group D-animals with blood pressure elevated in metacorticoid hypertension elicited by the administration of desoxycorticosterone acetate and sodium chloride. Group Eanimals with blood pressure elevated by repeated doses of Ephedrinum basicum solutio oleosa (100 mg/kg) every 2nd day during 2 weeks. Group R-rabbits with renal hypertension following unilateral nephrectomy and a partial renal artery ligation. Group $\mathrm{Na}$-animals receiving daily $2.5 \mathrm{ml} / \mathrm{kg}$ of $3 \% \mathrm{NaCl}$ solution hypodermically during 6 weeks. Group $\mathrm{K}$-animals receiving analogical amounts of $3 \% \mathrm{KGl}$ solution.

The sodium and potassium concentrations in samples of thoracic aorta, blood plasma and erythrocytes were determined with the use of a flame photometer (Cort and Fencl, 1957).

\section{RESULTS}

The mineral ion levels in the aorta, erythrocytes and plasma are quoted in the table. The concentrations of sodium and potassium ions in the thoracic aorta tissue are expressed in $\mathrm{mEq} / \mathrm{kg}$ of dry tissue, the ion concentrations in red blood cells and in the plasma in $\mathrm{mEq} / \mathrm{l}$. All numbers in the table are mean values with standard error.

\begin{tabular}{|c|c|c|c|c|c|c|}
\hline \multirow{2}{*}{ Group } & \multirow{2}{*}{$\begin{array}{l}\text { No. of } \\
\text { animal }\end{array}$} & \multicolumn{2}{|c|}{ Aorta } & \multirow{2}{*}{$\frac{\text { Erythrocyte }}{\mathrm{K}}$} & \multicolumn{2}{|c|}{ Blood plasma } \\
\hline & & $\mathrm{Na}$ & $K$ & & $\mathrm{Na}$ & K \\
\hline$N$ & 20 & $251 \pm 13$ & $130 \pm 7$ & $340 \pm 17$ & $221 \pm 12$ & $18.8 \pm 0.9$ \\
\hline D & 11 & $300 \pm 14$ & $162 \pm 8$ & $105 \pm 18$ & $248 \pm 14$ & $15.7 \pm 0.8$ \\
\hline$E$ & 7 & $276 \pm 18$ & $114 \pm 9$ & $474 \pm 25$ & $257 \pm 15$ & $19.5 \pm 1.2$ \\
\hline$R$ & 12 & $295 \pm 14$ & $146 \pm 11$ & $261 \pm 20$ & $252 \pm 13$ & $19.2 \pm 0.9$ \\
\hline $\mathrm{Na}$ & 8 & $280 \pm 14$ & $132 \pm 8$ & $263 \pm 17$ & $300 \pm 14$ & $13.6 \pm 0.7$ \\
\hline$K$ & 8 & $241 \pm 12$ & $165 \pm 13$ & $440 \pm 20$ & $267 \pm 13$ & $20.8 \pm 1.1$ \\
\hline
\end{tabular}

* Significant difference $(\mathrm{P}<0.01)$

Received for publication April 2, 1962. 


\section{DISGUSSION}

The author's conception of those biochemical changes in the vessel wall, in the blood and in the whole organism which lead to the pathologic function of the vessel bed is still rather incomplete. In recent years intensive attention has been paid to the ion metabolism in the wall of the aorta and minor vessels. A modern conception in this respect is presented by the theory of Raab (1959) expressing the importance of the ratio of sodium and potassium ions and of the concentration gradient between the inner of the cell and its environment. According to the experiments of Freed (1953 and 1959), Friedman (1959) and Raab (1959) the reactivity of the smooth muscle cells is depending upon this ion gradient, the sodium-potassium exchange being based on an energetic principle. From this point of view it furnishes a new and fruitfull conception of the electrochemical excitability of the cell in general. The aorta potassium is bound to a specific active protein (Laszt, 196I), and sodium seems to be bound even to mucopolysaccharides in the interstitial space of the media (Headings et al., 1960).

In animals made hypertensive after $\mathrm{DCA}+\mathrm{NaCl}$ administration the author has found an increase of both sodium and potassium in the aorta and a decrease of potassium in erythrocytes. There was a rise of plasma sodium and a fall of plasma potassium. These results are in accordance with those of other authors (Tobian and Redleaf, 1957 and 1958; Alexandrow et al., 1961).

After prolonged blood pressure elevation by ephedrine there was a slight decrease of potassium in the aorta (Raab, 1959) and further on a potassium increase in erythrocytes and a sodium rise in the plasma. These results may be compared with other findings in hypertension (Daniel and Dawkins, 1957; Tobian, 1958; Freed et al., 1959) within a certain scope only, because few investigators have used ephedrine so far.

The author's results in renal hypertension are not contradictory to several known findings of Friedmann et al. (1959), and Tobian and Redleaf (1957 and 1958). They were, however, often non-significant statistically in this experimental group.

In animals after $\mathrm{NaCl}$ administration the author has found only a slight increase of aortic sodium; the potassium in erythrocytes and in plasma was markedly decreased, whereas the plasma sodium was rather high.

Interesting were the findings in animals receiving $\mathrm{KGl}$ : In the aorta sodium was just slightly decreased, potassium on the contrary was markedly increased. In erythrocytes potassium was also elevated, but sodium only showed an increased level in the plasma.

The author stresses the specificity of our results in rabbits which can be compared with other data experienced in other animal species relatively only and not in absolute values.

\section{SUMMARY}

The influence of different types of experimental hypertension in rabbits upon the sodium and potassium ion level in the thoracic aorta, in erythrocytes and in the blood plasma was followed up. 
In metacorticoid hypertension after $\mathrm{DCA}+\mathrm{NaCl}$ there was a potassium fall in the plasma and in erythrocytes; the plasma sodium increased and in the aorta both ions rose.

After prolonged ephedrine administration sodium rose in the plasma and potassium rose in erythrocytes; the potassium content of the aorta slightly decreased.

In renal hypertension sodium slightly increased in the aorta and in the blood plasma, whereas the potassium content of erythrocytes slightly decreased.

After long-term $\mathrm{NaCl}$ administration sodium rose only in the plasma, whereas potassium decreased in both the plasma and erythrocytes. The prolonged $\mathrm{KCl}$ administration produced a rise of potassium in the aorta and also in erythrocytes, whereas the plasma sodium was found slightly increased.

\section{REFERENCES}

Alexandrow, D., W. Wysznacka and A. Backo (1961). Polski Arch. Med. Wewn. 31, 921.

Cort, H.J. and V. Fencl in Tělesné tekutiny, Ed. by SZdN, Prague (1957).

Daniel, E.E. and O. Dawkins (1957). Am. J. Physiol. 190, 71.

Freed, S.C., R.H. Rosenman and M. Friedman (1953). Ann. N.Y. Acad. Sci. 56, 637.

Freed, S.C., S. St. George and R.H. Rosenman (1959). Circulation Research 7, 219.

Friedman, S.M., G.L. Friedman and M. Nakashima (1959). Ibid. 7, 917.

Headings, V.E., P.A. Rondell and D.F. Bohr (1960). Am. J. Physiol. 199, 783.

Laszt, L. (1961). Nature 189, 230.

Raab, W. (1959). Am. J. Cardiol. 4, 752.

Tobian, L. (1958). Circulation 17, 768.

Tobian, L. and P.D. Redleaf (1957). Am. J. Physiol. 189, 451.

Tobian, L. and P.D. Redleaf (1958). Ibid. 192, 325.

Vacek, L. (1959). Scripta Med. Fac. Med. Univ. Brunensis et Palackyanae 32, 301.

Vacek, L. (1960). Arch. intern. pharmacodynamie 124, 461.

Vacek, L. and A. Texl (1960). Ibid. 128, 276. 